\title{
Diagnosa COVID-19 Chest X-Ray Menggunakan Arsitektur Inception Resnet
}

\author{
Adhitio Satyo Bayangkari Karno ${ }^{1, *}$, Dodi Arif ${ }^{2}$, Indra Sari Kusuma Wardhana ${ }^{3}$, \\ Eka Sally Moreta ${ }^{2}$ \\ ${ }^{1}$ Fakultas Teknologi Informasi; Universitas Gunadarma; e-mail: adh1t10.2@gmail.com \\ 2 Fakultas Teknologi Informasi; STMIK Jakarta STI\&K; dodi.arif@gmail.com, \\ ekamoreta@gmail.com \\ ${ }^{3}$ Magister Teknologi Informasi; STMIK Jakarta STI\&K; e-mail: indraskw@gmail.com \\ *Korespondensi: e-mail: adh1t10.2@gmail.com
}

Diterima: 23 Juni 2021; Review: 26 Juni 2021; Disetujui: 29 Juni 2021; Diterbitkan: 3 Juli 2021

\begin{abstract}
The availability of medical aids in adequate quantities is very much needed to assist the work of the medical staff in dealing with the very large number of Covid patients. Artificial Intelligence (Al) with the Deep Learning (DL) method, especially the Convolution Neural Network (CNN), is able to diagnose Chest $X$-ray images generated by the Computer Tomography Scanner (C.T. Scan) against certain diseases (Covid). Inception Resnet Version 2 architecture was used in this study to train a dataset of 4000 images, consisting of 4 classifications namely covid, normal, lung opacity and viral pneumonia with 1,000 images each. The results of the study with 50 epoch training obtained very good values for the accuracy of training and validation of $95.5 \%$ and $91.8 \%$, respectively. The test with 4000 image dataset obtained 98\% accuracy testing, with the precision of each class being Covid (99\%), Lung_Opacity (97\%), Normal (99\%) and Viral pneumonia (99\%).
\end{abstract}

Keywords: Inception Resnet V2, Convolution Neral Network, Deep Learning, COVID-19, Chest-Xray

\begin{abstract}
Abstrak
Ketersediaan alat bantu medis dalam jumlah memadai sangat diperlukan untuk membantu kerja para medis dalam menangani jumlah pasien Covid yang sangat banyak. Artificial Intellience (Al) dengan metode Deep Learning (DL), khususnya Convolution Neural Network (CNN), mampu mendiagnosa image Chest XRay yang dihasilkan oleh alat Computer Tomography Scanner (CT Scan) terhadap penyakit tertentu (Covid). Arsitektur Inception Resnet Versi 2 dipergunakan dalam penelitian ini untuk melakukan trainning dataset 4000 image, terdiri dari 4 klasifikasi yaitu covid, normal, lung opacity dan viral pneumonia masing-masing dengan jumlah data 1.000 image. Hasil penelitian dengan trainning 50 epoch diperoleh nilai yang sangat baik untuk akurasi trainning dan validasi sebesar $95,5 \%$ dan $91,8 \%$. Uji testing dengan jumlah data uji 4000 image diperoleh akurasi testing 98\%, dengan presisi tiap kelas adalah Covid (99\%), Lung_Opacity (97\%), Normal (99\%) dan Viral pneumonia (99\%).
\end{abstract}

Kata kunci: Inception Resnet V2, Convolution Neral Network, Deep Learning, COVID-19, Chest-Xray 


\section{Pendahuluan}

Dua bulan kemudian setelah pesta pora berlebihan di India (Januari 2021) karena telah mampu mengalahkan pandemi covid, menimbulkan malapetaka yang sangat luar biasa bagi negara tersebut. Tsunami Covid gelombang ke dua di India (Maret 2021) telah memecahkan rekor angka penambahan kasus dan kematian tertinggi didunia. Konfirmasi positif dalam waktu sehari mencapai angka 401.993 orang di India (https://health.detik.com/fotohealth/d5579554/potret-ratusan-mayat-di-sungai-gangga-bak-kuburan-massal). Lumpuhnya lembaga kesehatan dan para medis terlihat sudah tidak mampu lagi menangani banjirnya pasien covid, mengakibatkan kematian yang sangat tinggi (Gambar 1). Kurangnya ketersediaan alat bantu medis mempersulit penanganan, ditambah lagi masalah lembaga kremasi yang kehabisan kayu bakar untuk prosesi pembakaran mayat, mengakibatkan banyak mayat mengapung disepanjang sungai di India.

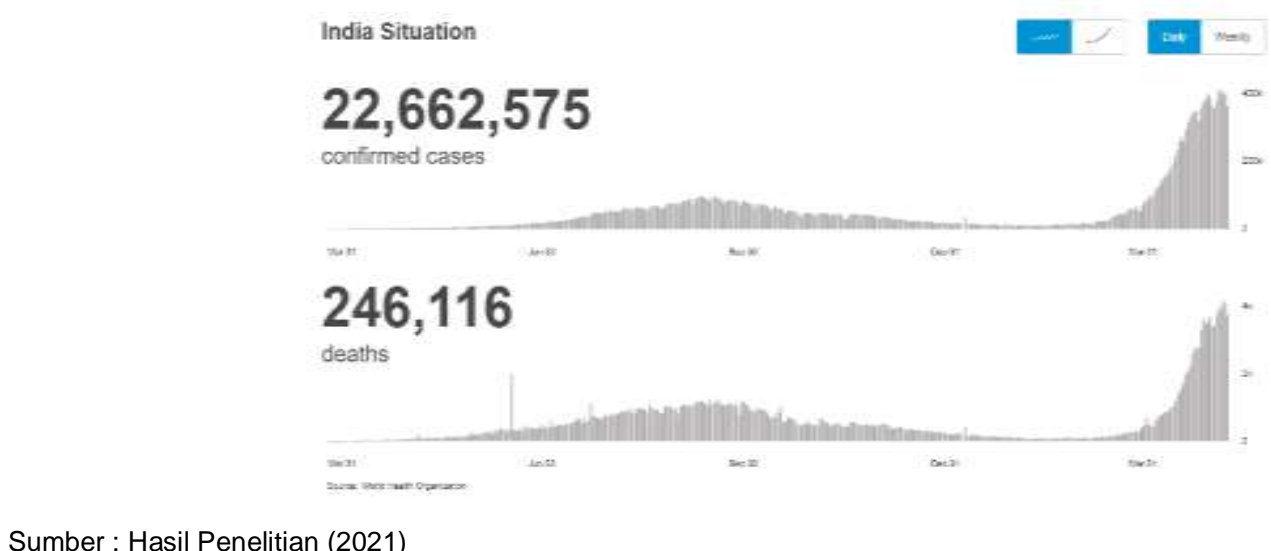

Gambar 1. Data Covid di India (Sumber WHO)

Dalam kondisi normal untuk dapat mendiagnosa covid dari image chest xray dari seorang pasien, memerlukan orang dengan keahlian medis khusus dalam bidang radiologi. Terbatasnya jumlah tenaga medis dengan keahlian ini, menjadikan diagnosa memerlukan waktu lama. Terlebih dalam kondisi pandemi (Tsunami Covid), timpangnya jumlah antara para medis dan pasien merupakan suatu masalah besar yang mengakibatkan tingkat kematian sangat tinggi karena ketimampuan penanganan pasien oleh para medis di India. Pemanfaatan Al (metode CNN) mampu memprediksi covid dari image chest xray, akan sangat membantu meringankan kerja para medis. Diagnosa akan lebih cepat dilakukan, dengan tingkat akurasi yang tinggi dan biaya yang sangat murah.

Untuk dapat menggunakan metode $\mathrm{CNN}$, mesin perlu dilatih (trainning) dengan image dalam jumlah yang cukup besar, semakin banyak jumlah image yang dipergunakan maka mesin akan cenderung lebih pandai. Untuk meningkatkan akurasi model dari arsitektur yang 
digunakan akan sangat siknifikan. Beberapa perbandingan menunjukan dengan arstitektur yang berbeda untuk melakukan sejumlah training dengan hasil akurasi yang semakin tinggi. Sampai saat ini pun masih terus dilakukan berbagai penelitian untuk merancang arsitektur baru guna meningkatkan akurasi. Namun sampai saat ini pengembangan arsitektur CNN lebih cenderung kepada penambahan layer yang semakin dalam, ketimbang untuk merancang layer yang effisien. Dengan layer yang dalam tentu akan mempengaruhi waktu operasi dan performansi dari infrastruktur komputer yang digunakan. CNN dengan arsitektur Inception Resnet model V2 dipilih dalam penelitian ini untuk memperoleh hasil akurasi yang tinggi dengan tetap mempertimabangkan kemampuan computer yang digunakan (Gambar 2).

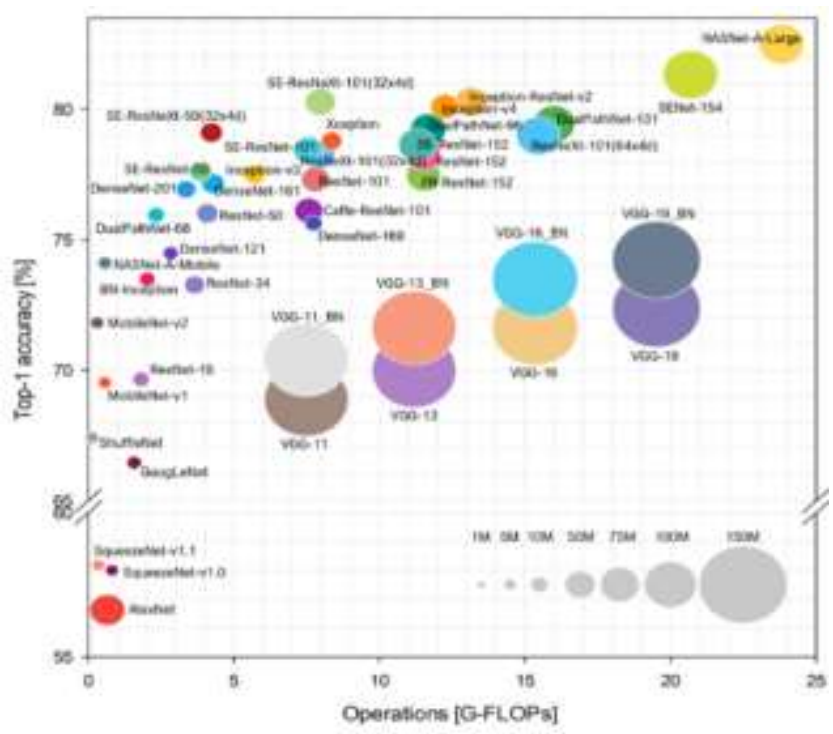

Sumber : Hasil Penelitian (2018)

Gambar 2. Komparasi Inception ResNet [Sumber IEEE]

\section{Metode Penelitian}

$\begin{array}{llll}\text { Sebanyak } & 4.000 & \text { dataset }\end{array}$

(https://www.kaggle.com/tawsifurrahman/covid19-radiography-database) dipergunakan dalam penelitian ini. Secara klinis setiap image chest-xray di klasifikasikan ke dalam 4 kelas (Sisodia, S., S., Nair, S., and Khobragade, P., 2020), dengan jumlah dataset tiap kelas sebagai berikut (Gambar3):

$$
\begin{array}{ll}
0 \text { - Normal } & 1.000(25 \%) \\
1 \text { - Viral Pneumonia } & 1.000(25 \%) \\
2 \text { - Lung_Opacity } & 1.000(25 \%) \\
3 \text { - Covid } & 1.000(25 \%)
\end{array}
$$




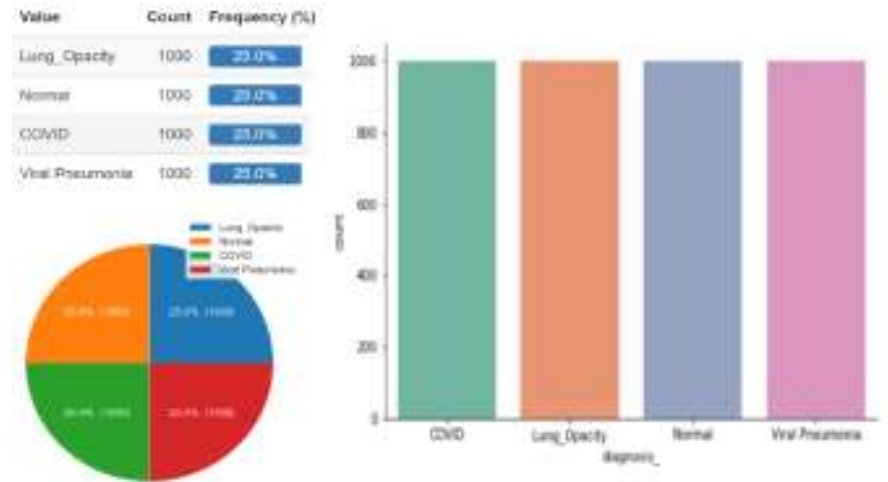

Sumber : Hasil Penelitian (2021)

Gambar 3. Pie dan histogram dataset

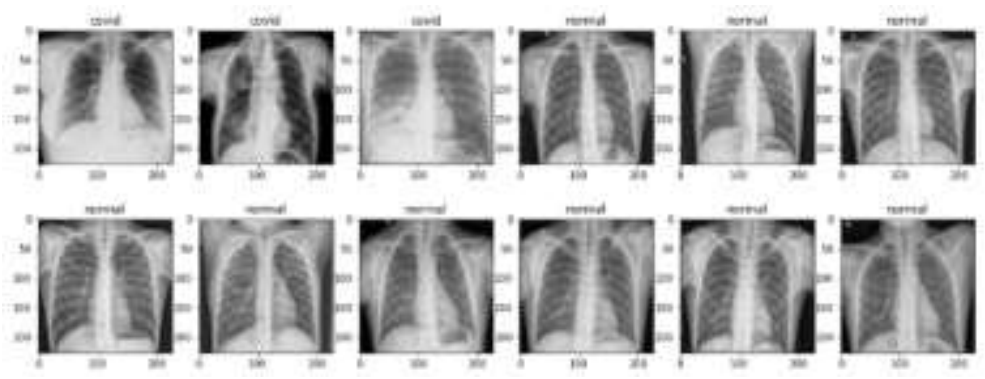

Sumber : Hasil Penelitian (2021)

Gambar 4. Dataset Image Chest XRay

Telah menjadi hal yang umum untuk meningkatkan akurasi adalah dengan menambah sumberdaya yang ada. Sebagai upaya pengembangan CNN, Szegedy (2014) memperkenalkan Inception dalam papernya yang berjudul "Going Deeper with Convolution" C. (Szegedy, et all. 2015). Convolution adalah upaya ektraksi image untuk memperoleh model dalam bemtuk matrik kernel. Proses ini dilakukan dengan melakukan filterisasi yang bergeser dengan nilai stride tertentu pada suatu input image. Selanjutnya hasil dari convolution menjadi input bagian fully connected untuk proses klasifikasi. 


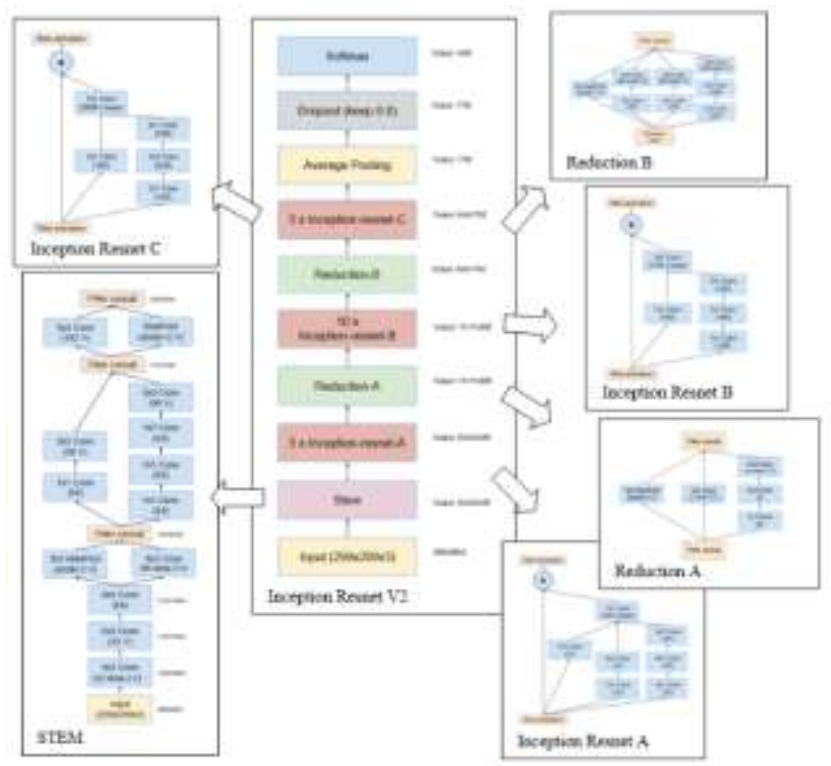

Sumber : Hasil Penelitian (2021)

Gambar 5. Skema Inception Resnet V2 dan blok modul
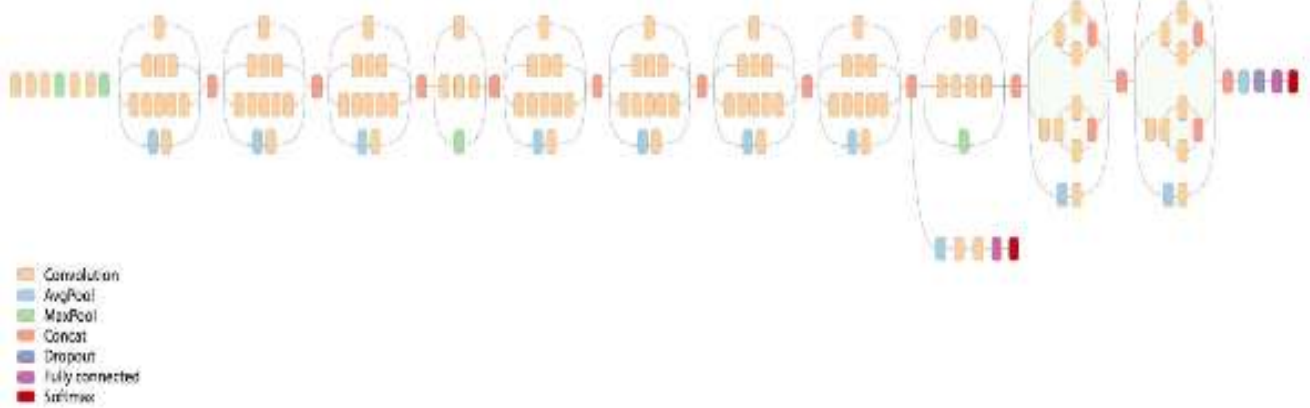

Sumber : Hasil Penelitian (2020)

Gambar 6. Diagram kompres skema Inception Resnet V2 (https://medium.com )[Q]

Banyak pengembangan arsitektur CNN lebih mengarah pada penumpukan layer yang dalam. Layer yang semakin dalam dapat mengakibatkan over fitting dan vanishing gradien. Vanishing gradien ini menyebabkan timgkat kesalaham (loss) bukan berkurang tapi justru semakin bertambah selain waktu komputasi yang lama/mahal. Untuk menghindari layer yang semakin dalam, inception membuat arsitektur yang cenderung melebar dari pada jaringan yang mendalam. Upaya lain yang dilakukan adalah meningkatkan kecepatan komputasi dengan cara mengurai matrik konvolusi besar menjadi ukuran yang lebih kecil (Tan, Mingxing Quoc V. Le, 2020) (Gambar 5-6). Hasil pengembangan Inception Resnet V2 menghasilkan akurasi yang lebih baik dibanding versi sebelumnya (Tabel 1 ) 
Tabel 1. Perbandingan akurasi Inception Resnet dengan versi sebelumnya [O].

\begin{tabular}{ccc}
\hline Model & $\begin{array}{c}\text { Top-1 } \\
\text { Accuracy }\end{array}$ & $\begin{array}{c}\text { Top-5 } \\
\text { Accuracy }\end{array}$ \\
\hline Inception-ResNet-v2 & 80.4 & 95.3 \\
\hline Inception V3 & 78.0 & 93.9 \\
\hline ResNet 152 & 76.8 & 93.2 \\
\hline ResNet V2 200 & $79.9^{*}$ & $95.2^{*}$ \\
\hline
\end{tabular}

Sumber : Hasil Penelitian (2021)

\section{Hasil dan Pembahasan}

Karena keterbatasan infrastuktur, maka penelitian ini hanya menggunakan jumlah data 4.000 image dan melakukan 50 epoch dengan memperoleh nilai akurasi trainning dan validasi sangat baik yaitu masing 99,6\% dan 91,8\%. (Gambar 8). Terlihat grafik akurasi dan loss sudah tidak mengalami banyak perubahan setelah trainning 50 epoch (gambar 9 dan 10).

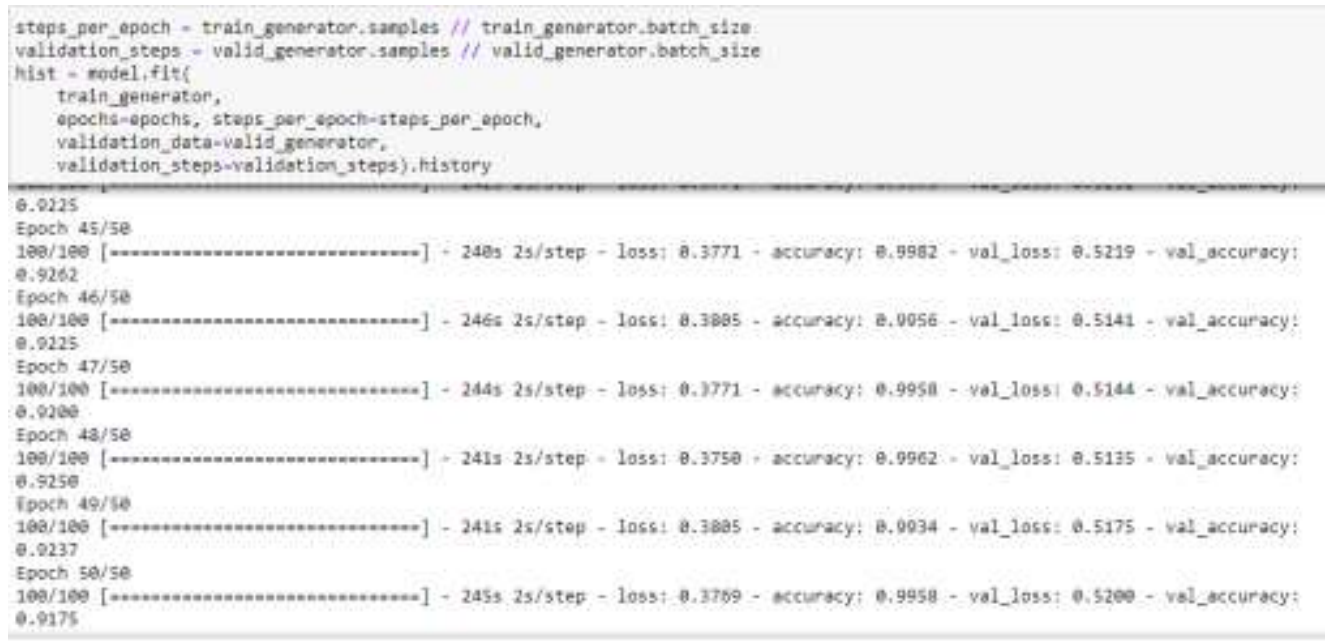

Sumber : Hasil Penelitian (2021)

Gambar 7. Akurasi trainning $95,5 \%$ dan validasi $91,8 \%$ 


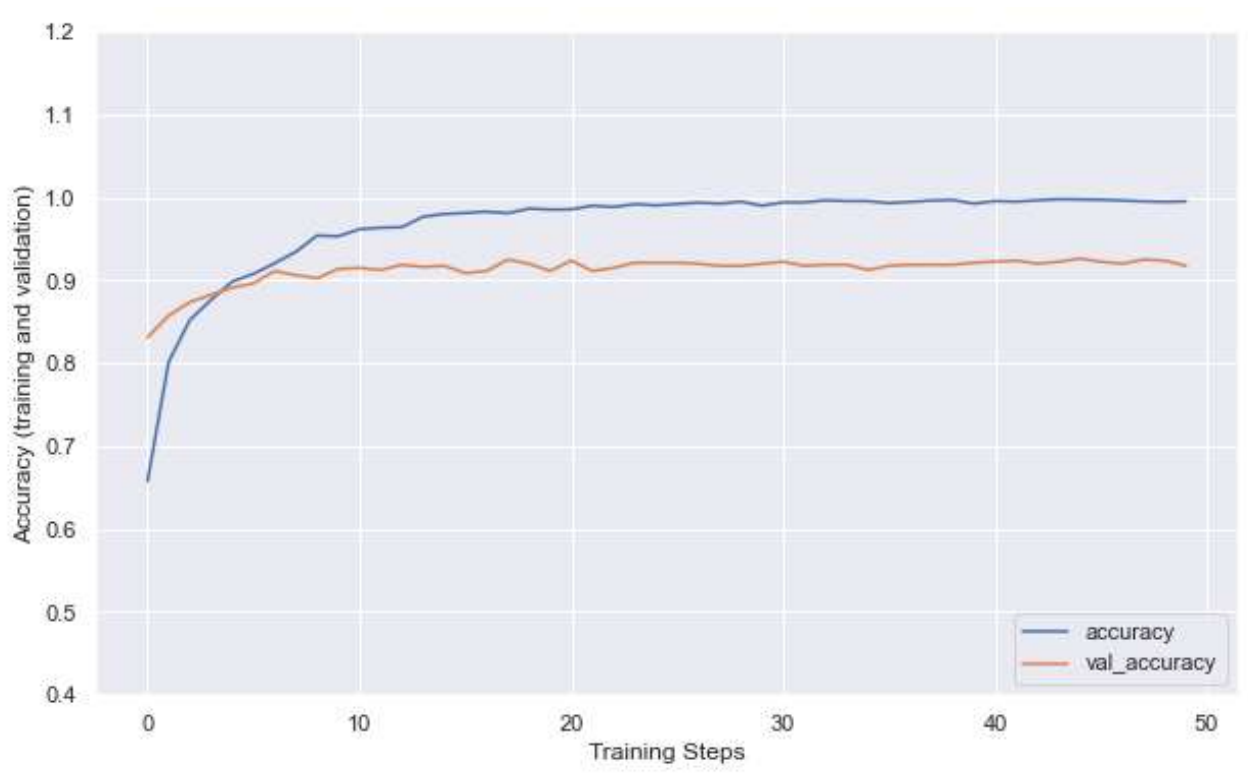

Sumber : Hasil Penelitian (2021)

Gambar 8. Grafik akurasi trainning dan testing

: Hasil Penelitian (2021)

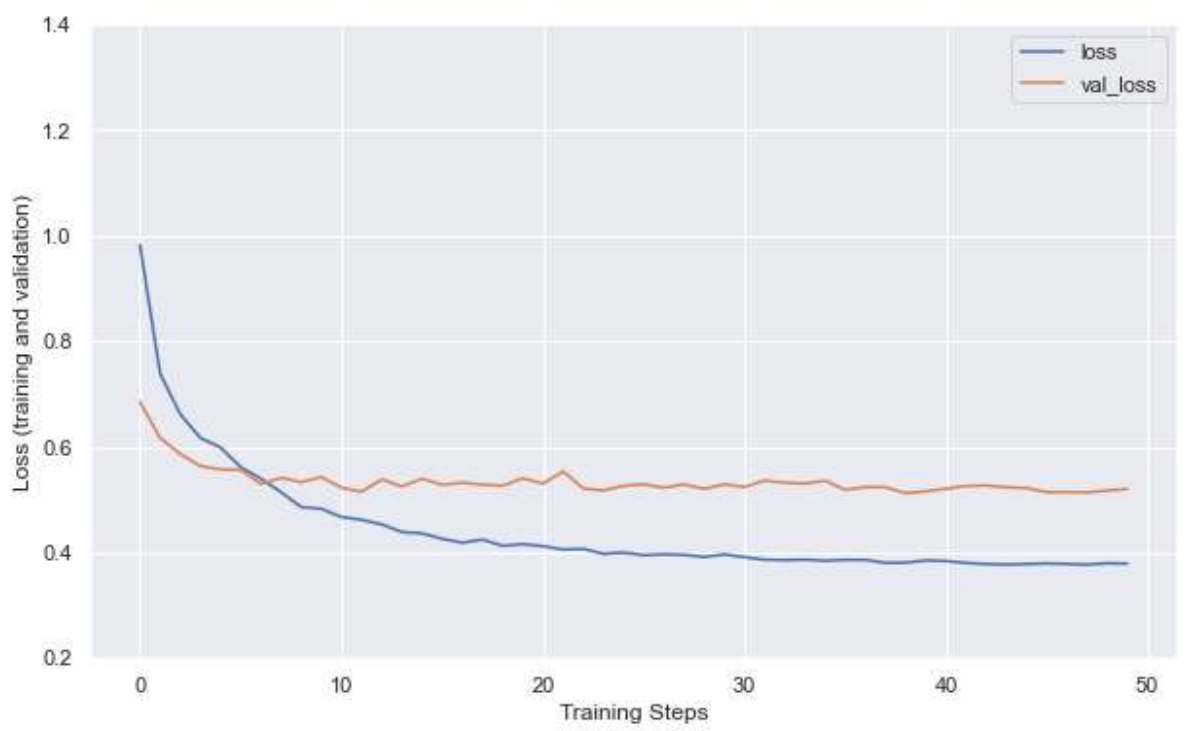

Sumber : Hasil Penelitian (2021)

Gambar 9. Grafik Loss Value trainning dan testing

Dari hasil training yang telah dilakukan diperoleh model matrik kernel. Model ini dapat dipergunakan untuk menguji image data yang belum diketahui labelnya. Agar lebih menyakinkan maka dilakukan pengujian Kembali dengan menggunakan 4000 dataset data image chest-xray, terdiri dari 4 kelas masing-masing berjumlah 1000 image. Hasil pengujian ini diperoleh nilai presisi untuk tiap kelas sebagai berikut: 
- COVID adalah 979 dari 993, sehingga presisinya sebesar $99 \%$.

- Lung Opacity 984 dari 1.013, sehingga presisinya sebesar $97 \%$.

- Normal adalah 982 dari 996, sehingga presisinya sebesar 99\%.

- Pneumonia, 991 dari 998, sehingga presisinya sebesar $99 \%$.

Detail perhitungan untuk megukur presisi lainnya ditunjukan dalam bentuk tabel 1 , sebagai berikut :

Tabel 2. Penjelasan report klasifikasi

\begin{tabular}{c|c}
\hline COVID & A \\
\hline Lung Opacity & B \\
\hline Normal & C \\
\hline Viral Pneumonia & D \\
\hline
\end{tabular}

\begin{tabular}{|c|c|c|c|c|c|c|}
\hline & & \multicolumn{4}{|c|}{ Sebenarnya } & \multirow[b]{2}{*}{ Support } \\
\hline & & A & B & C & D & \\
\hline \multirow{5}{*}{ 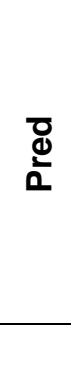 } & A & 979 & 16 & 5 & 0 & 1.000 \\
\hline & B & 12 & 984 & 1 & 3 & 1.000 \\
\hline & C & 2 & 12 & 982 & 4 & 1.000 \\
\hline & D & 0 & 1 & 8 & 991 & 1.000 \\
\hline & & 993 & 1.013 & 996 & 998 & 4.000 \\
\hline
\end{tabular}

\begin{tabular}{c|c|c|c}
\hline & Precision & Recall & f1-score \\
\hline A & $979 / 990=0.99$ & $979 / 1000=0.98$ & $2^{*} 979 /(993+1000)=0.98$ \\
\hline B & $984 / 1043=0.97$ & $984 / 1000=0.98$ & $2^{*} 984 /(1013+1000)=0.98$ \\
\hline C & $982 / 988=0.99$ & $982 / 1000=0.98$ & $2^{*} 982 /(996+1000)=0.98$ \\
\hline D & $991 / 979=0.99$ & $991 / 1000=0.99$ & $2^{*} 991 /(998+1000)=0.99$ \\
\hline
\end{tabular}

Sumber : Hasil Penelitian (2021)

Accuracy $=(952+969+943+960) / 4000=0.96$ 


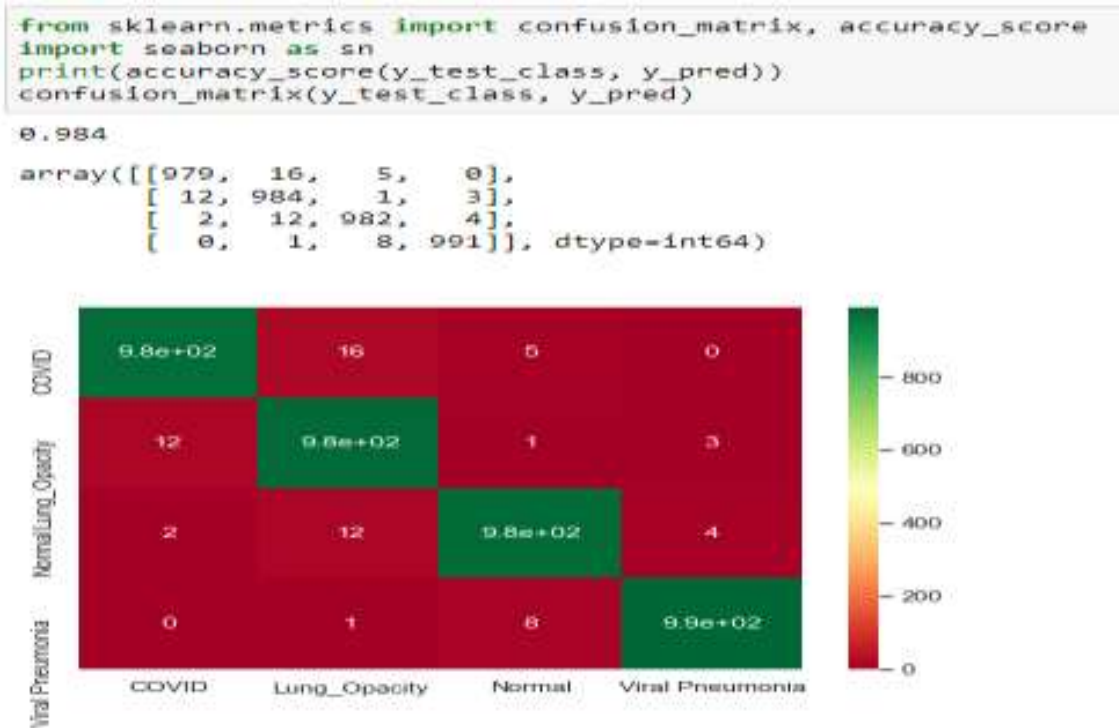

Sumber : Hasil Penelitian (2021)

Gambar 10. Matrik Confusion

Modul sklearn phyton dapat dipergunakan untuk mengukur akurasi dan memvisualisasikan matrik cofusion seperti yang ditampilkan dalam Gambar 9 dan 10.

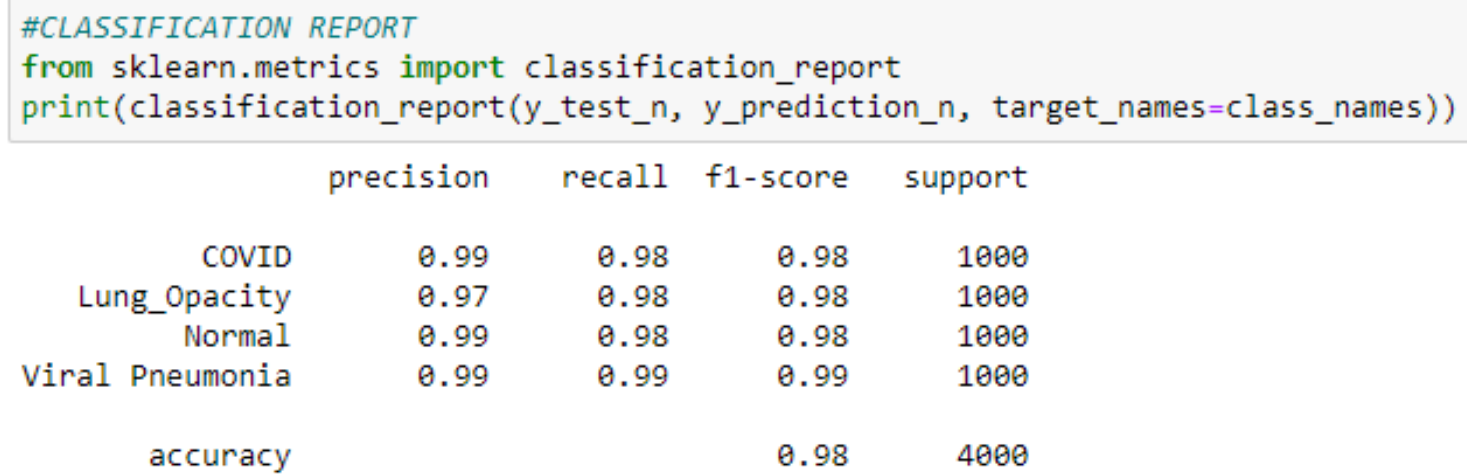

Sumber : Hasil Penelitian (2021)

Gambar 11. Report Klasifikasi

\section{Kesimpulan}

- Hasil dari penelitian untuk memprediksi jenis penyakit covid dan pneumonia lainnya dari data image Chest X Ray menggunakan metode CNN dan arsitektur Inception Resnet Versi 2 adalah sangat baik. Diperoleh hasil dengan nilai presisi tiap kelas lebih dari 95\% yaitu: Covid (99\%), Lung_Opacity (97\%), Normal (99\%), Viral_Pneumonia (99\%). Untuk nilai akurasi secara keseluruhan adalah 98\%.

- Pemanfaatan Al dalam dunia kedokteran (medis) adalah sangat penting, karena dapat membantu meringankan kerja para medis. Terutama untuk diagnosa Covid dapat dilaksanakan dengan cepat, tepat dan biaya yang sangat terjangkau. 
- Untuk pengambilan data image pasien dapat dilakukan dengan cepat dengan menggunakan peralatan CT Scan yang hampir tersedia di semua rumah sakit tiap kota di Indonesia.

- Hasil model dari penelitian ini dapat digunakan (embeding) dalam bentuk mobile internet atau dalam bentuk sistim yang berbasis web. Sehingga setiap saat dan di manapun berada pasien dapat melakukan scanning dan memperoleh hasil prediksi langsung (real time) dengan cepat.

\section{Daftar Pustaka}

Al-Dulaimi K, Chandran V, Nguyen K, Banks J, Tomeo-Reyes I. Benchmarking hep-2 specimen cells classification using linear discriminant analysis on higher order spectra features of cell shape. Pattern Recogn Lett. 2019;125:534-41.

Brownlee, J., (2018). Use Early Stopping to Halt the Training of Neural Networks At the Right Time. https://machinelearningmastery.com/how-to-stop-training-deep-neural-networks-atthe-right-time-using-early-stopping/

C. Szegedy, et all. (2015). Going deeper with convolutions. In Proceedings of CVPR, pages 19, 2015. https://arxiv.org/abs/1409.4842.

Hasan MK, Islam MM, Hashem MMA. Mathematical model development to detect breast cancer using multigene genetic programming. In: 2016 5th Int. Conf. Informatics, Electron. Vis. IEEE; 2016. p. 574-9. https://doi.org/10.1109/ ICIEV.2016.7760068

http://prosiding.unipma.ac.id/index.php/SENATIK/article/view/1474.

Islam MM, Rahaman A, Islam MR. Development of smart healthcare monitoring system in loT environment. SN Comput Sci 2020; 1:185. https://doi.org/10.1007/ s42979-020-00195-y.

Jiang X. Feature extraction for image recognition and computer vision. In: Proc. - 2009 2nd IEEE Int. Conf. Comput. Sci. Inf. Technol. ICCSIT. vol. 2009; 2009. p. 1-15. https://doi.org/10.1109/ICCSIT.2009.5235014.

Karno, ASB., Hastomo, W., (2020). FUTURE PREDICTION OF COVID-19 IN INDONESIA USING DEEP LEARNING. Seminar Nasional Teknologi Informasi dan Komunikasi (SENATIK)-2020. E-ISSN: 2685-5615.

Karno, ASB., Hastomo, W., (2020). OPTIMALISASI DATA TERBATAS PREDIKSI JANGKA PANJANG COVID-19 DENGAN KOMBINASI LSTM DAN GRU. Prosiding SeNTIK STI\&K, 2020. https://ejournal.jak-stik.ac.id/index.php/sentik/article/view/296.

Liu W, Wang Z, Liu X, Zeng N, Liu Y, Alsaadi FE. A survey of deep neural network architectures and their applications. Neurocomputing. 2017;234:11-26.

Sisodia, S., S., Nair, S., and Khobragade, P., (2020). Diabetic Retinal Fundus Images: Preprocessing and Feature Extraction for Early Detection of Diabetic Retinopathy. National Institute of Technology, Raipur. https://dx.doi.org/10.13005/bpj/1148.

Tan, Mingxing Quoc V. Le, (2020) EfficientNet: Rethinking Model Scaling for Convolutional Neural Networks. ICML 2019 https://arxiv.org/abs/1905.11946

Tian H, Chen SC, Shyu ML. Evolutionary programming based deep learning feature selection and network construction for visual data classification. Inf Syst Front. 2020;22(5):1053-66

Young T, Hazarika D, Poria S, Cambria E. Recent trends in deep learning based natural language processing. IEEE Comput Intell Mag. 2018;13(3):55-75. 